\title{
A Liturgical Relation with the Spatial Configuration and Architectural Form of The Catholic Church
}

\author{
Rudy Trisno ${ }^{\text {a }}$, Fermanto Lianto ${ }^{\mathrm{a}^{*}}$ \\ ${ }^{a}$ Department of Architecture, Tarumanagara University, Jakarta 11440, Indonesia \\ E-mail: *fermantol@ft.untar.ac.id
}

\begin{abstract}
The phenomenon of the Catholic church after the Second Vatican Council has lost the expression of its sacred form. This study aims to trace the liturgical relation with the spatial configuration of the architecture form from the Catholic Church to get the Ideogram and Godly symbol that will influence the form of architecture of the Catholic Church and can be used as the interpretation of the case studies. The methodology used in this study is firstly, describing liturgical activities associated with the sacred form approach from Eliade, Hoffman, Jones, Barrie, and Martasudjita to trace the sacred concept of the functions of the liturgy and relate it with the anatomical approach of the floor from Salura. Secondly, obtain a reference to the spatial configuration and reference to the architectural form of the Catholic Church. The aim of all these approaches is to obtain the spatial aspect configuration and form aspects. The findings of the spatial configuration or Ideogram and form of Catholic Church architecture are the Godly symbols, as well as the framework for the interpretation of case studies. The results conclude that the Catholic Church form is a symbol of divinity and Ideogram. Thus, if the scope of the environment, tread, building, and figure corresponds to the aspect of reference in creating sacred value, then the architecture of the Catholic church assumable radiating a sacred expression.
\end{abstract}

Keywords — catholic church; godly symbol; ideogram; sacred interpretation; spatial configuration.

\section{INTRODUCTION}

The phenomenon of the Catholic Church form before and after the Vatican II council was diverse because of the development of technology and the lack of standard rules to describe the architecture form of the Catholic Church. On the other hand, the liturgical activity in the Catholic Church has been standard from the early age until present. This phenomenon has caused the fade of the architectural form of the Catholic Church even before the Second Vatican Council. The fade is mainly due to the rapid technological advances, especially in the structure field. This issue has progressively worsened after the era of Second Vatican Council and has caused the increase of the fade of the sacred form of the Catholic Church.

The fading phenomenon of the form of the Catholic Church creates the fade of the sacred value of the form of the Catholic Church. This issue has raised a concern from general public and Pope Benedict XVI [1]. Hence this has been very interesting topic in this study. The main issue from this study is the relationship between function and form. The main function of Catholic Church is for liturgy while the architectural form is the spatial configuration

The use and the benefit obtained from this study are: first, the understanding of the relationship between standard liturgy function and the Catholic Church's architecture sacred form. Second, to fill the theoretical and practical treasury so that it could be implemented in the Catholic Church's initial design. Thirdly, to give input to all stakeholders that would like to build and design the Catholic Church. Fourthly, to place the sacred value of the Catholic Church in this modern era.

\section{MATERIALS AND METHODS}

The liturgy is the main activity in the Catholic church. In principle, the basic structure of the liturgical year consists of the Easter circle and the Christmas circle. However, the church celebrates the Easter mystery once a week on Sunday; Nevertheless, 'Sacrosanctum Concilium' itself stresses the importance of the weekly liturgical mass by stating that the Sunday mass is the foundation and core of all liturgical years [2]. Therefore, the liturgical discussion in this study is limited only to the liturgy performed on Sunday.

The form of the building referred in this study is the composition of the upper elements (roof and ceiling) - the middle (walls and columns) - the bottom (floor), which form an intact unity [3]. This composition included the nature and the quality of the surface elements: color, scale, as well as 
ornamentation attached to each element of the building scopes.

The basis of the analysis carried out in this study is the relationship between the function and the architectural forms [4]. Although, the two aspects of this condition could not be separated [5]. The analysis in this study emphasizes the relation between the functional aspect of the liturgy and its form.

The first step is to describe all the liturgical activities in the Catholic Church. Elaboration of the liturgical activities conducted every weekly [6]. This recording is conducted using Martasudjita's approach, and the symbols of the liturgy are obtained [7], [8]. It comprises of the Profane MovementSacred, which includes Narthex, Nave and Sanctuary. The Sacred concept in the liturgy requires the spatial dimension of imagination and sacred form from Eliade, Jones, Hoffman, and Barrie approach [9]-[12], which includes spatial configuration aspects and building form aspects. Salura's approach covers the scope of environment anatomy from both interior and exterior [13].

The second step based on all the approaches in the first step to obtaining a reference the spatial configuration and reference the Catholic Church architectural forms that support the liturgy and can be used as a guide for study cases as well as the design of buildings, especially the Catholic church. Based on the first and second steps, we have obtained the purpose of the relationship between the liturgy function concept with the form concept and spatial configuration of the church building for the meaning of its sacred value.

\section{RESULTS AND DISCUSSION}

Liturgy relations between the form and the spatial configuration of the Catholic Church architecture.

\section{A. First Step}

History records that since the beginning, the church always starts with a preparatory stage, where people dip their finger into the holy water and make a cross sign before entering the Church building [14]. Therefore, this study elaborates on the complete liturgical stage, which includes the preparation stage, the opening rite, the liturgy of the word, the Eucharistic liturgy, and the closing rite. The liturgical stage requires an area of space and specific space qualities requirements.

The following will describe the area required for the entire rite in the liturgy with a description of a procession performed: The first area is the narthex (less-sacred); it is divided into two parts: 'exonarthex' and 'esonarthex'. 'Exonarthex' is an area that stretches from the entrance of the site to the entrance of the church building, while 'esonarthex' is the entrance area in the building that is located towards a more sacred area (nave) [15].

In general, this area is the place where people make the cross sign with the holy water, and it is a symbol of selfcleansing. One can assume that the preparation area before the people enter the core of the ritual celebration, while the next area is the nave. This area is the sacred part of the Catholic Church that is located in the middle of a church building stretching from the entrance (narthex) to the altar in the sanctuary area. Symbolically, the nave is an area for the ordinary people to become a representation of the assembly of the people in horizontal.

The third area is the sanctuary, which is the most sacred area in the Catholic Church. Because in this area there is an altar that is the center of all liturgical celebrations, this area is generally marked with a higher level than other areas. The sanctuary area is also called the priest's home because this area is only to priests and Eucharistic ministers, and the area is distinguished from the people who attend the celebration in the nave area. In line with the description above, the following diagram shows the zoning of the liturgical activity, as shown in Fig. 1.

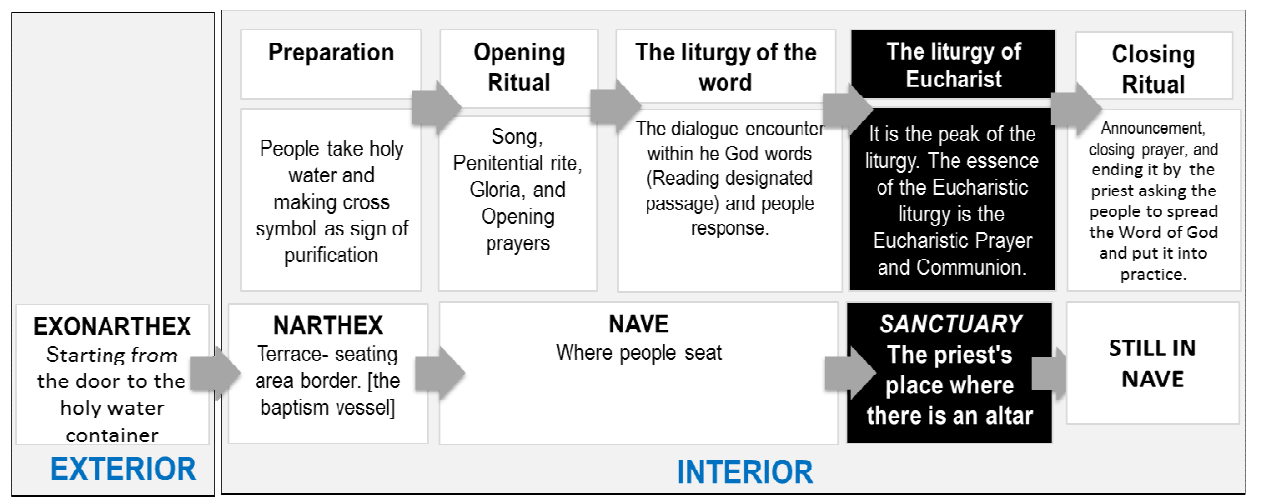

Fig. 1 Zoning of the liturgical activity

The following section will describe the literature that describes the general sacred concept. The purpose of this analysis seeks the sacred concept that underlay the spatial configuration as well as the building form to correspond to the creation of the sacred value contribution.

1) Eliade Approach: Eliade has become the foundation for the universal principle of the sacred value. Before discussing the basic concepts of spatial configuration and the form of sacred buildings, it is necessary to understand the essential principle of sacred value is the existence of religious people (homo religious). Furthermore, how humans respond to the existence of sacred values through hierarchy and Axis-Mundi understanding as an embodiment of axial 
orientation [9]. The following will discuss the sacred value principle:

- The sacred and the religious human: The basic example of 'hirofani' is the Sacred Manifestation in some objects commonly encountered in everyday life, such as rocks and trees, or religious buildings, to the highest degree such as the incarnation of God in Jesus Christ. 'Hirofani' becomes a new order that manifests the cosmic center marked by Axis-Mundi, which literally can be defined as the center of the world.

- Axis-Mundi as the form of axial orientation: Based on the description by Eliade regarding the axis-mundi, the sacred space has existential value for the religious human; because nothing can begin, nothing can be done without orientation. Furthermore, the orientation itself requires the existence of a point, where 'hirofani' takes place and act as a "center". A place is called sacred because divine power is present in that place; the divine power in that place moves a human to orient itself to that place [9]. Thus, it can be concluded that the human understanding of the sacred space is based on the concept of orientation.

2) Jones Approach: Based on Eliade's thesis, Jones developed Eliade reflection. In this study, we will discuss the concept of orientation and symmetrical axis, the order of space and form of the building based on the concept of hierarchy, monumental scale, and lighting arrangement to support the creation of the sacred expression on the form of the building [9], [10].

- Symmetrical composition: In his book, Jones reviewed the orientation aspect by describing the application of specific orientation concepts in the architecture. One of the principles that manage the objects in nature is the principle of equilibrium, which generally manifested through symmetrical compositions [10]. The symmetrical composition of religious buildings is applied not only in spatial order but also in the appearance of each element of the building.

- Sacred hierarchy: In addition to this assessment, Jones also added the importance of hierarchical aspects. Using this understanding as a foundation, Jones argues that the design form of the religious building must be seen concerning the religious events that are taken place in that building. With or without realization, ritual activities always have stages ranging from the less sacred to the most sacred [9]. In the context of architecture, this can be realized through the order of the concept of hierarchy. For example, the sacred area is generally located at the site that is furthest away from the site entrance and is marked with a clear boundary [10]. Although not expressed explicitly, but this is based on the concept of horizontal hierarchy. In addition to being manifested horizontally, the sacred area can also be distinguished from other areas through the compositions that emphasize the vertical aspect. The higher the elevation of a place, the higher the value of the sacredness, compared to other places that are in a lower elevation. Hence, it is not surprising that the architecture of religious buildings always has a wall, a roof, or a tall tower with a vertical impression dominating its appearance. The vertical element is considered adequate to "shorten" the distance between humans and God. Therefore, acting as a symbol of human desire that always wants to be close to God.

- Monumental scale: a unique and dominant composition can manifest the expression of the building form representing the presence of the Creator. The building not only acts as a shelter but rather as a monumental "sculpture", with a scale much larger than the human scale (non-anthropomorphic) to express symbolic.

- Lighting: Light has a symbolic role that is directly related to the religious human's perception of sacredness. It is universally believed that light is a symbol of the light of God's love that saves man from darkness and evil. Thus, it is perceived that the presence of light always characterizes the sacred area [16].

3) Barrie's Approach: In this book, there are several principles about the arrangement of architectural elements in the context of sacredness. Complementing the approach of Eliade and Jones, Barrie reviews the embodiment of the hierarchical concept of the sacred space horizontally through spatial sequences, as well as the principle of equilibrium underlying the sacred proportions and the sacred geometry [9], [10], [12].

- Spatial sequences based on hierarchical concepts: The review of path \& place departs from the understanding that religious activities are understood as symbolic activities, describing the journey of humans from a profane state toward the sacred in order to form a relationship with the Creator [11]. The religious view, "path" also becomes a symbol of the journey to the center world, seeking the ultimate truth or the divine. Ideally, the road does not start from the inside area of the building, but it is started on the exterior area, e.g., on the site area. The presence of a wide site will assist humans greatly in preparing themselves for following ritual activities in the building. The extent site on the façade also allows the mass of the main building as a destination to be easily identified by observers and can be seen in full. The sequence of places from the profane-area of preparation-as right destination illustrates the sequence of the journey to something sacred.

- The principle of balance underlies the creation of sacred geometry: This book also discussed the principles that govern the relationship between the part and the whole. Based on Vitruvius's view, it could be summarized that one of the fundamental principles governing the relationship between part and whole is through symmetry [17]. This principle basically connects the harmonious relation between parts to create something that is whole. Although not explicitly stated, it is believed that symmetry is created when the sections are structured on the principle of equilibrium. This principle can be seen in the geometric form; Starting from the circle, triangle, rectangle, to a variant of a triangular composition that 
forms a hexagon and an octagon, all of which is symmetrical form. These geometric forms are sacred because it is believed to be a representation of the orderliness of the cosmos structure; a symbol of world stability, as well as a symbol of nature harmony. Thus, the principle of equilibrium underlying geometric shapes can also complement the hierarchical and orientation concepts.

4) Hoffman's Approach: The Concept of Exposing Symbolic Elements: Hofmann is an architect that conducts research on the topic of sacred. He mentioned that in addition to the aspect of orientation and hierarchy, there is one aspect that is equally important in the formation of sacred space, namely the identification of elements that contain symbolic meaning. Hoffman groups three categories of sacred space; architectural, archetypal, and atmospheric elements [11]. The following will discuss all three:

- Identification of the architectural elements outside and inside the building: Fundamentally, the identification of sacred architectural elements can be classified into three. First is the identification of architectural elements from outside the site or outside the page. Second is the identification of architectural elements inside the site or the yard. The gateway is representing the boundary, that the path is the symbol of the spiritual journey, endpoint destination, which serves as a symbol for the achievement of spiritual insight. For example, the gate expresses clear access for humans. While the place as the destination of the pilgrimage should be the focus in the site, as well as it should be predominant than other buildings. Third is the identification of architectural elements in the building. The interior elements include portals, roads, and destinations. Portal is functionally interpreted as an entrance area, and it also symbolically acts as a "boundary" to enter buildings that are considered more sacred than the site area. After passing the portal, users directed to the path that connects a portal and a sacred area as the primary focus (such as the altar or 'mihrab').

- Identification of archetypal element: Archetypal consists of three types of elements. First is the universal element. This type includes the four primordial elements of land as a symbol of fertility and healing, air or sky as a symbol of heaven, water as a symbol of purification, and fire as rebirth. Second is the religious elements (mythic) such as pillars and trees, rocks, and mountains that are also considered sacred because it is verticality displayed by the element, and it is believed to act as a physical manifestation of the axis-mundi. Third is the geometric elements such as circles, rectangles, or triangles that have been trusted to be the symbols of the orderly structure of the cosmos, which at the same time represents the dialogue between God and humans.

- Atmospheric ambiguities: Apart from identifying through the element identification-physical element, the sacred can also be realized through atmospheric ambiguities/ambiguous ambiance. This includes the silence \& noise in which silence can be a symbol of God 's presence. Darkness-Light is a darkness that presents a light, or the presence of light can support the creation of the experience of Divine presence. Emptiness-Profusion focuses on the difference of the rhythm and arrangement of elements to affirm the hierarchy between the profane and sacred areas. Humility-Monumentality that focuses on how the monumentality displayed by the form of the building can make people feel small and low when facing the Creator.

Based on the study of Martasudjita, Eliade, Jones, Barrie, Hoffman, and Salura [7], [9]-[13], it can be concluded that the aspects of the architecture support the ritual function, and it also supports the creation of sacred values. This can be grouped into two, i.e., in spatial configuration, as well as specifically on the expression of the building form. The results of the literature study show that aspects of spatial configuration, location, orientation and hierarchy, zoning, and axis, while the building form includes the top-middledown element that shapes the whole unity as well as the basic form (geometry). The arrangement of light effect will strengthen the scale of the space, the scale of the building, the appearance of colors, the texture of the material, the scoping elements, and the divine symbols on the building's facade or the interior. This understanding becomes the basis for the reference formulation of the spatial configuration and building form, based on the sacred concept and can be distinguished as follows:

5) Spatial Configuration Based on the Sacred Concepts: Aspects that are included in the spatial configuration is not only related to the interior design, but also on the exterior design that covers the site area and its environment. Concerning the design of the outer space, the spatial configuration that is following the sacred concept are:

- First, the existence of the inter-zone sequence in place. For instance, on the site, the closer an area to the religious building, the higher the hierarchy.

- Second, the placement of the boundary between the place zone. Ideally, the further down the place tends to create a clearer hierarchy that allows people to comprehend the "spiritual journey".

- Third, through the location of the establishment of a religious building. To show its virtue, ideally, the location should be free-standing and not directly being next to other locations.

- Fourth, the location of the building establishment can be seen from a distance by the people, not obstructed by vegetation or other buildings. Visual access to the mass of the main building becomes essential, so the people realize that meeting God (symbolized by the religious building) is gradual, and it is a clear journey of a direction and purpose. Fifth is concerning the area. For buildings to be viewed in their entity, ideally, the places tend to have wide visibility.

- Sixth is relation to the contours. To show the building virtue, ideally, the location tends to be on a higher contour compared to other building contours around it. Ideally, the location tends to be on the axis of the road and/or the site. 
In association with the interior design, the spatial configuration that is following the sacred concepts are:

- First, the arrangement of space in buildings that tend to be symmetrical to create the axis. The symmetrical form that supports the creation of the axis is believed to be the perfect form. Universally, the symmetrical form is a symbol of the perfection of God; however, it has a meaning of stability, tranquility, and robustness that is always being longed for by humans.

- Second, the blueprint tends to have a clear direction towards the most sacred area, as a manifestation of human beliefs about Axis-mundi, the center of sacredness. Third, the composition of the threedimensional form gradually tends to lead upwards, so that the concept of hierarchy or the difference of quality in every space zoning can be seen visually.

6) Building Form Based on Sacred Concept: In addition to spatial configurations that emphasize composition, aspects of the design of building form that include top-middlebottom element composition. This building pays attention to the scale, ornamentation, building form, as well as the quality of the material that will form the appearance and texture of the material. References of building form following the concept of sacred are described as follows.

- First, the composition of buildings that tends to sharpen upward.

- Second, through the composition of the appearance of the buildings that tends to look symmetrical.

- Third, with the expression of material, surface, and color that tends to contrast or shine. The use of contrasting materials, surfaces, and colors is believed to create the focus of the building. Whereas with a glowing display (for example, with the use of lights), it allows the building to be visible even at night.

- Fourth, the form of the building that has a monumental or non-anthropometry scale that makes humans feel small and low when facing the Creator. Based on related literature, the building has a monumental scale if it has a height of more than 10 (ten) times the height of humans [18].

- Fifth, through a form that tends to sharpen upward.

- Sixth, if the scoping element has a different form/unique form that is different than others to highlight the virtue of a area and to confirm the hierarchy between profane and sacred areas.

- Seven, with the presence of ornamentation that symbolizes God. The ornamentation can be presented by paintings, mosaics, sculptures, stained glass, or carvings and symbols-symbols of a specific numbers and colors.

From the scope of building anatomy that is based on the theoretical studies in the previous section, it can be understood that besides the form and space in the building, the sacred value of Catholic church architecture is also strongly influenced by the site and the environment of the building. In line with that understanding, Salura reveals that a building can't be separated from its environment. Therefore, ideally, the architecture should be traced based on the widest range to the most specific scope, ranging from the scope of the surrounding environment, the scope of the site, the scope of the form, the scope of the figure, to the scope of the cycle [13].

In contrast to other studies that tend to discuss the form of Catholic church architecture partially, in this study, the anatomy of each of the case studies will be described comprehensively. The full description of the anatomy of the building allows the analysis of spatial configuration and the shape of the building to be discussed in detail in this case study. Here are descriptions of the four scopes of building anatomy.

- First, the environment scope. The explanation of this scope contains a description of the relation between the site study case and the existing pattern site and the road in the surrounding environment.

- Second, the site contains a description of the relationship between building mass and open space in the case study.

- Third, the relationship between all elements, both structural and non-structural, with an activity room in the building.

- Fourth, the relationship between the boundary quality or the form of the building with the requirements of activities.

\section{B. Second Step}

Based on the approach from the first step, a reference could be obtained for the spatial configuration and form of the Catholic church building to support the liturgical demands could as well as the procedure that can be applied to trace the case study.

1) Spatial Configuration Reference Architecture that Supports the Catholic Church Liturgy: a reference could be made to formulate spatial configuration on the design of the internal and external spaces to support the liturgy, namely as follows:

- First, the area around the element composition of the narthex-nave-sanctuary tended to leads up and shaped upwards. Specifically, in the context of the architectural design of the church, some literature says that the Church building is successful if it is inspiring the feelings of the people, and this usually is strongly influenced by the presence of vertical elements that dominate the look of the building [19].

- Second, the composition of the scope element and the arrangement of the space tends to be symmetrically balanced.

- Third, the basic shape of narthex-nave-sanctuary horizontally tends to have a clear, facing direction. Not only acting as a symbol of the perfection of God, the symmetrical room arrangement could also help to direct people's point of view towards the sanctuary and the altar as the center of the liturgical celebration [18].

- Fourth, the composition of the three-dimensional form of the entire narthex-nave-sanctuary area gradually tends to shaped upwards. Illustrations that could portray the description could be seen in Fig. 2. Since the sanctuary area is a sacred area, it should ideally be the area with the highest elevation compared to the other areas. 
Therefore, the spatial layout of the church should be structured accordingly to reflect the hierarchical order of the people and the diversity of human tasks. It is also mentioned that the sanctuary area is the place where the altar is built when the word of God is proclaimed, and the priests, deacons, and other servants perform their duties. Therefore ideally, those areas are made distinctive compared to the other area. One of the ways is by floor elevation.

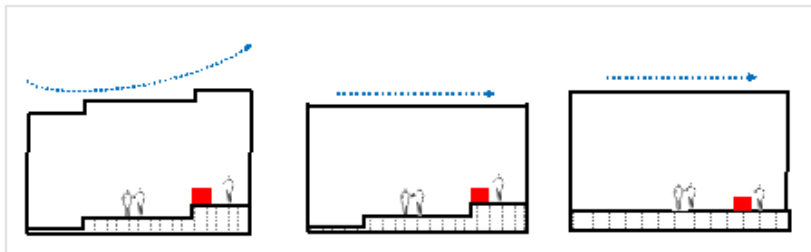

1. Floor and ceiling that shaped like a staircase (left figure) and flat (middle and right figure). The floor and ceiling elevation that shaped like a staircase with the highest elevation at the sanctuary (left figure) are more able to show liturgical motion than the middle and right figure.

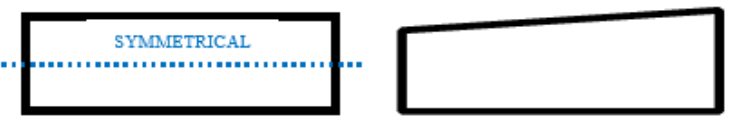

2. The sketches and the scopes are symmetrical (left figure) and not symmetrical (right figure). The sketches and the symmetrical facade on the left figure, are believed to be more capable of supporting the liturgy

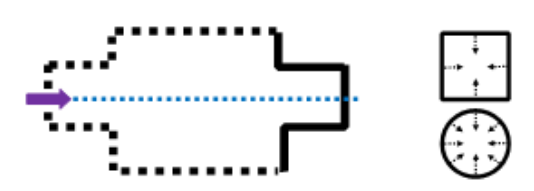

3. A sketch that has a certain direction (left figure) compared to the sketch that has a center but did not have a certain direction (right figure). The sketch that has a certain direction on the left figure is believed to be more in line with the liturgical flow

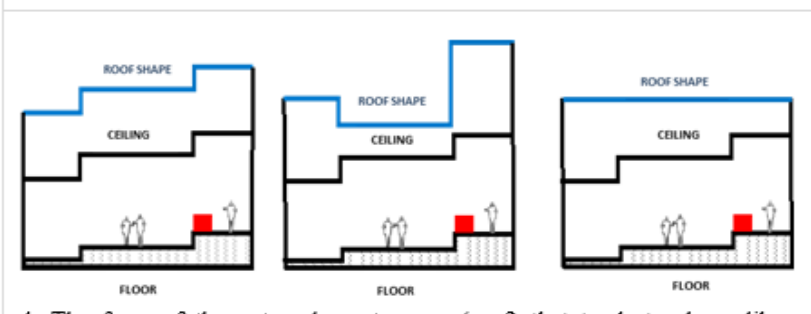

4. The form of the outer element scope (roof) that tends to shape like a staircase following the floor elevation (left figure) with the one that shaped like a staircase but unsuitable (right figure) and flat (right figure). The form of the staircase element, according to the floor elevation, is ideal in reflecting the liturgical motion.

Fig. 2 References to a spatial configuration interpretation that supports the liturgy in interior design

The idea of the form and the three-dimensional form and spaces that are most capable of supporting the liturgy is in Fig. 2 and formulated in the form of a latitude Ideogram. The understanding of the terms Ideogram, according to the Indonesian Big Dictionary/official dictionary, is the graphic sign that is used to draw a graphical representation and to describe the part of speech as a sentence statement. Thus, Ideograms can also be regarded as a meaningful logogram as morphemic characters (such as writing in Japanese and Chinese characters). The Ideogram concept that can be applied to analyze the suitability between the liturgy and the inner space, as well as the outer space of the architecture of the Catholic Church, can be found in Fig. 3.

In regards to the design of the outer space, the spatial configuration reference that supports the liturgy is what enables buildings to be identified and recognized as a Church building from a distance by people. This will support the liturgy as it helps people to prepare themselves before entering the site and the church building to follow the sacred liturgy.

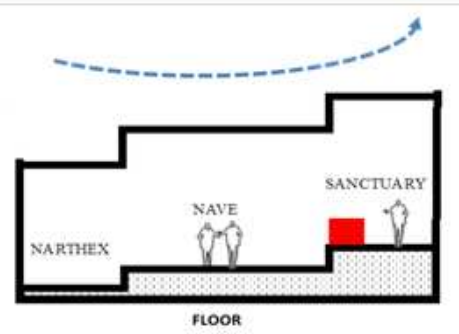

1. Interior Ideogram (inner space) for the Catholic Church's architecture

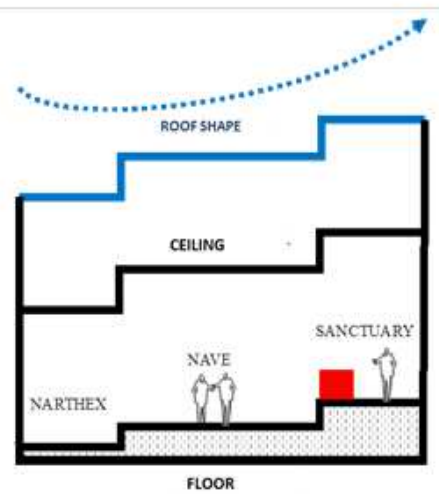

2. A combined ideogram between the inner and outer space of the Catholic Church's architecture

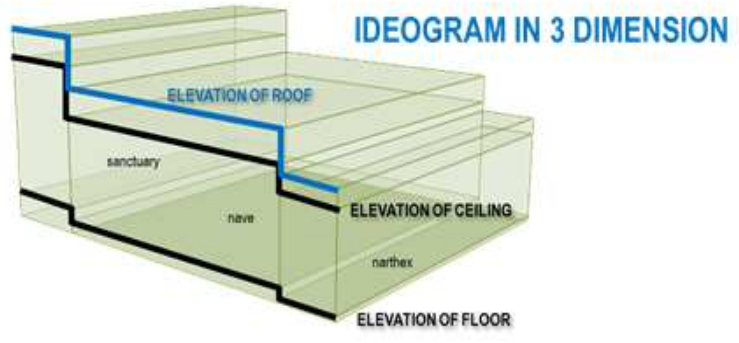

3. Ideogram in $3 \mathrm{D}$

Fig. 3 Inner and outer space architecture of the Catholic Church as well as the Ideogram in 3D (three dimensions)

The references are described as follows:

- First, the form of the building is in line with the sequences between the zones of the place. Based on previous studies, it is mentioned that the order of worship acts as a symbol of the human journey from profane to sacred state. Thus, the place that acts as a vessel of the activity is ideally aligned with religious activities, where the deeper the place is, the higher the hierarchy is. To highlight the hierarchical differences and for it to be seen visually. Usually, the transition between profane and sacred areas is marked by the 
presence of the boundaries in the form of gates or fences.

- Second, the form of the church building is in line with the placement of the zoning boundaries, i.e., the deeper the place is, the more obvious the hierarchy becomes.

- Third, the form of the church building is in line with the location and its environment, which tends not to stand too close to other places (free-standing).

- Fourth, the form reciprocates with continuous visual access (not blocked by vegetation or other buildings) to the building location.

- Fifth, the form reciprocates with the area to obtain absolute visibility that allows the whole building to be seen from a distant.

- Sixth, the form reciprocates with the contours of the place that tends to have higher elevations. Other than to show the building's virtue, the higher elevation for the building's position is also intended for buildings to be seen from a distance and to be identified by observers, as well as expressing a vertical impression.

- Seventh, the expression of the properties form reciprocates with the chosen location that allows the building to be the focus at their surroundings; the location tends to be at the road axis. Fig. 4 shows the illustration of this description.

2) Reference for Catholic Church Building Forms that Support the Liturgy: Form references that supports the liturgy, as shown in Fig. 5 are:

- First, the scope of the sanctuary area has material, surface, and color that tends to contrast or shine. It has been described in the previous section that, that the sanctuary area is the most sacred area; therefore, this area should be better designed compared to other areas. The use of contrasting materials or the form of the sanctuary areas tends to be different from others, supporting people to focus their attention on the sanctuary. As for the light arrangement, light is not only to assert a spatial hierarchy; the openings on the scaffolding and ceiling allow the entry of light to support the creation of a sacred experience to feel the Divine's presence.

- Second, it is the nave-narthex-sanctuary scopes that tend to have monumental or non-anthropometric scales. Specifically, on the architecture of the Catholic Church, there is a literature that mentioned that to be perceived as a form that has a monumental scale, the height of the building or the inner space should be ten times the height of humans [18].

- Third, attach the ornaments as a divine symbol to the nave-narthex-sanctuary scopes. Pope Benedict XVI emphasized the importance of ornamentation in the form of paintings, mosaics, sculptures, stained glass, carvings, and specific numbers and colors in a Church.

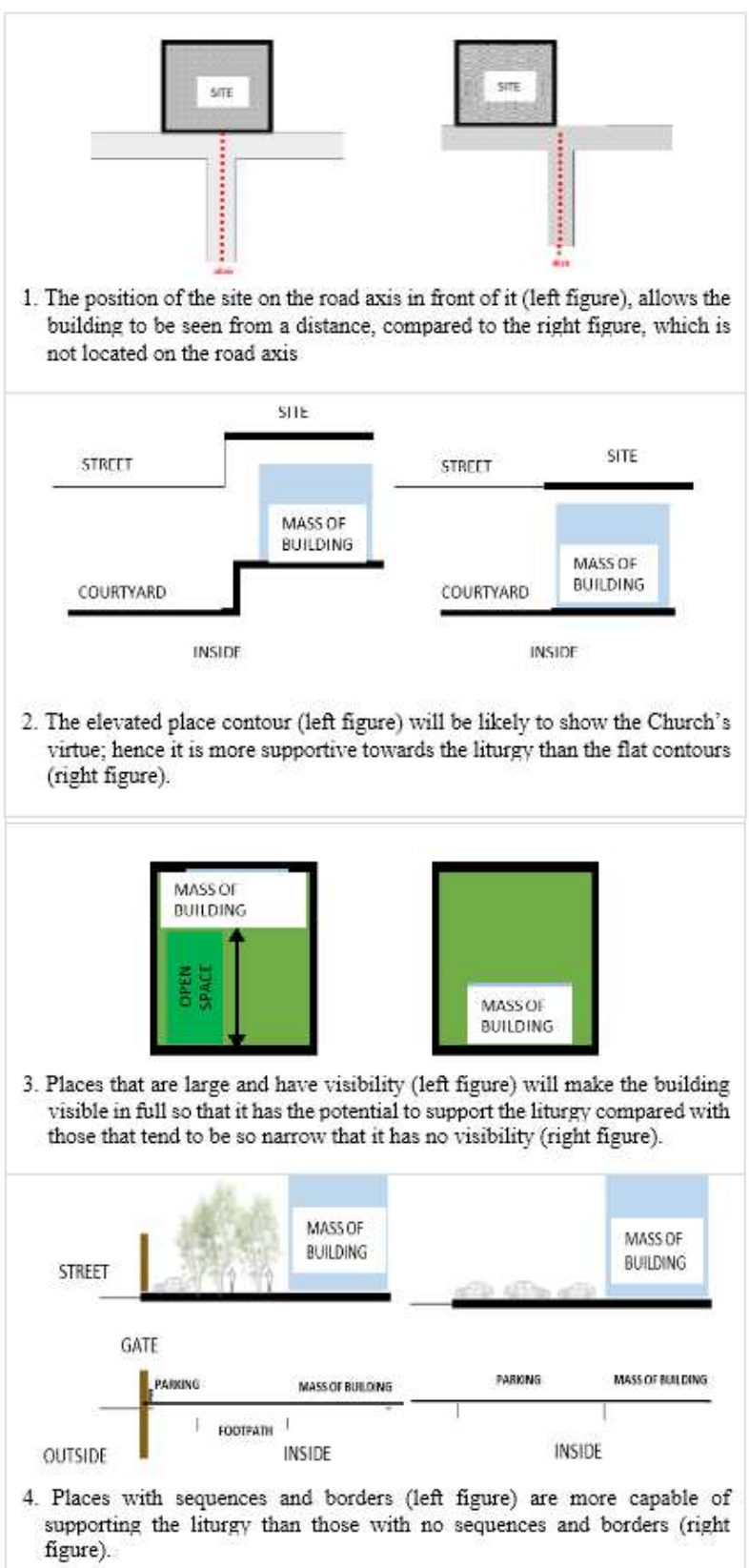

Fig. 4 References for a spatial configuration interpretation tools that support the liturgy for the design of the outer space

The Catholic Church's architecture must be laden with sacred ornamentation because it becomes a visual representation of an invisible God [20], [21]. The existence of ornamentation depicting God, Jesus, the Holy Spirit, or the Saints serves to commemorate the figure of the saints or specific events and the provision of the contents of Scripture in the form of pictures [15]; hence people are more responsive towards the message conveyed and it is easily understood. Moreover, liturgical equipment such as altars crosses, and tabernacles must be in a position that is easily visible by the people. The presence of this liturgical instrument not only allows the liturgy to be correctly conveyed but also able to bring the people to understand and perceive the meaning of the celebration of the Holy Eucharist better, thus contributing to the active participation as required by the Second Vatican Council. 


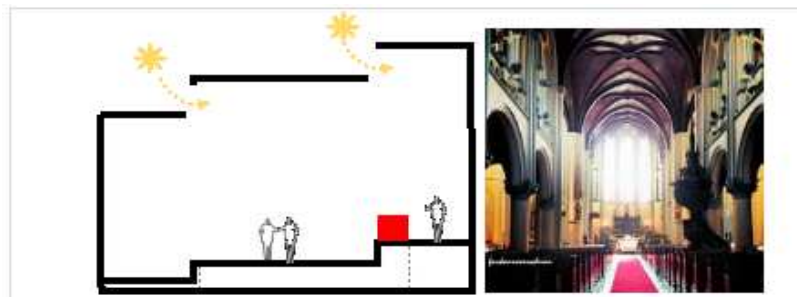

1. Opening on the ceiling and roofing element that allows the light entry is believed to support the creation of a sacred experience better and feel the Divine presence.

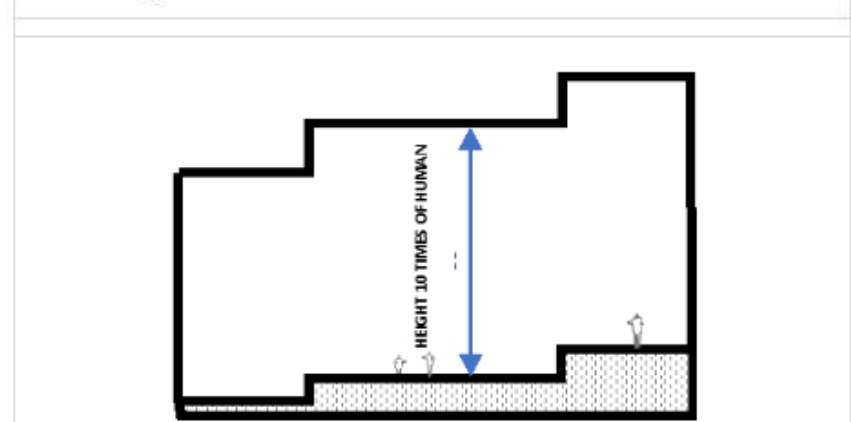

2. The monumental or non-anthropometry height of inner space scope (Ceiling) with a height of at least ten times the height of a human is believed to be more supportive towards the liturgy.

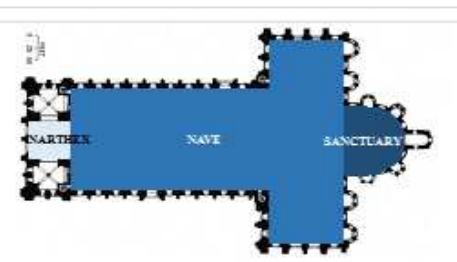

3. The shape of the arch in the sanctuary that distinguishes from other areas that tend to have a rectangular shape.

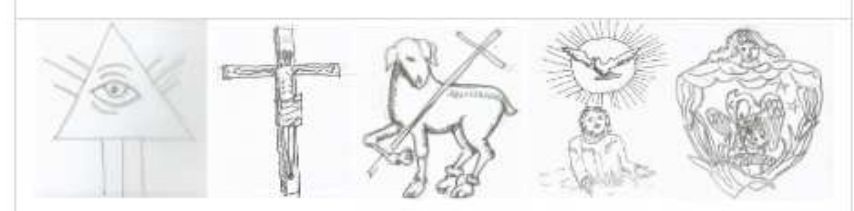

4. Symbolic Ornamentation. The Divine (from left to right figure): Eye of God symbolizing God the Father, Cross of Jesus, Agnus Dei (Lamb of God) symbolizing Jesus, Dove symbolizing the Holy Spirit, and the wholly Pelican.

Fig. 5 References as a means of interpretation of the Catholic church building forms that are in line with the liturgy

\section{CONCLUSION}

Based on the analysis and findings, the function relation is the liturgy and the form of the Catholic Church. The findings are as follows: First, the reference to the spatial configuration of the Catholic Church architecture that supports the liturgy is in the Ideogram, as shown in Fig. 3. Second, the reference to Catholic Church building forms that supports the liturgy is the Divine symbol, as shown in Fig. 5. Third, the spatial configuration or Ideogram is referencing to the outer design that supports the liturgy in Fig. 4.

Hence, research for the case study is described as follows:

\section{A. Describing the Case Study's Physical Building}

Fundamentally, a description of the building's physical recording before the analysis is necessary. The descriptions are not only performed on two-dimensional images, but also on the three-dimensional building. In line with the description in the introduction, it could be understood that the appearance of architectural forms cannot be separated from the interpretation of the observer or the user. An observer who only has a view from a distance will undoubtedly be different from users that do activities inside it. In order to be thoroughly described, the building must be viewed based on visibility.

In this study, the position of the building observation point and its inner space is determined by the movement of the people; from passing outside the site to the inner site and in the building:

- First, observations of buildings on the site are carried out from the site entrance to the site boundary, which directly faces the main entrance of the building.

- Second, using three points for the observation of the ornamentation attached to the inner space of the building and the quality of the figure from three points. The first point is at the entrance, the second point is in the center of the nave area, and the third point is in the area between the nave and the sanctuary.

\section{B. Analyze Each Case Study Based on the Scope Stage}

The physical description of the building is encountered with a predefined spatial configuration reference and the form of the building:

1) The Environment Scope with reference as follows:

- The form composition directs and sharpened upward

- The form tends to be balanced and symmetrical

- The appearance of materials, surfaces, colors tends to contrast with the appearance of the surrounding

- The scale of the form tends to be monumental

- Display Divinity symbol ornamentation

- There is a boundary that separates the site with the surrounding environment which clarifies the hierarchy

- The site tends to not stick with the other sites (freeStanding)

- Extensive visual access and visibility towards the site

- The sites are on a higher contour

- Site is on the road axis

2) The Site Scope with reference as follows:

- The deeper the site is, the higher the site hierarchy

- The Church building mass does not stick

- Clear visual access and wide visibility towards the Church Building

- The mass of the Church is on a higher contour than others and is in the site axis

3) The Building Scope with reference as follows:

- The site plan tends to be symmetrical and has a facing direction

- Narthex-Nave-Sanctuary floor elevation is following the inner scope Ideogram

- Tends to have a monumental scale

- Ornaments that is attached to space as a Divinity symbol

4) The Figure Scope with reference as follows:

- The composition of the outer element of NarthexNave-Sanctuary is in line with the Ideogram

- Material quality that is not only for the audio and visual buffer but as a light filter 
Based on this, the reference that will be encountered in the case study is the composition of the outer element (narthex-nave-sanctuary) that tends to have an upward direction, or in other words, in line with the Ideogram of the outer scope. Similarly, the expression of the scoping element has a quality that is not only able to be the audible and visual buffer from the outside, but also as a light filter.

\section{ACKNOWLEDGMENT}

We express our sincere gratitude to the teaching staff and friends from the architecture department of Tarumanagara University and Parahyangan Catholic University, which has supported this research.

\section{REFERENCES}

[1] Llovera. http://vaticaninsider.lastampa.it. Retrieved July 2014

[2] Dokumen Gereja Katolik. Sacrosantum Concilium. Point 106. 2012.

[3] T. T. Evensen. Archetypes in Architecture. London: Norwegian University Press. 1987.

[4] R. Trisno \& F. Lianto. Relationship Between Function-Form in The Expression of Architectural Creation. SageSubmissions. Preprint. posted on 03.09.2019. https://doi.org/10.31124/advance.8275322.v1.

[5] P. Salura \& B. Fauzy. The Ever-rotating Aspects of Function-FormMeaning in Architecture, International Journal of Basic and Applied Scientific Research. Vol. 2(7), pp. 7086-7090. 2012. http://www.purnamasalura.com/uploads/3/2/0/3/32036609/ffm.pdf.

[6] Konfrensi Wali Gereja. Pedoman Umum Missale Romawi. Jakarta: Nusa Indah. 2002.

[7] E. Martasudjita, Pr. Liturgi Pengantar untuk Studi dan Praksis Liturgi. Yogyakarta: Kanisius. 2011.
[8] F. W. Dillistone. The Power of Symbols. Yogyakarta: Kanisius. 2002.

[9] M. Eliade. The Sacred and The Profane. First publication. Translated by Nurwanto. Yogyakarta: Fajar Pustaka Baru. 2002.

[10] L. Jones. The Hermeneutics of Sacred Architecture. Cambridge, Massachusetts: Harvard University Press. 2000.

[11] D. R. Hoffman. Seeking the Sacred in Contempory Relgious Architecture. Ohio: The Kent State University Press. 2010.

[12] T. Barrie. The Sacred In-between the Mediating Roles of Architecture. New York: Routledge. 2010.

[13] P. Salura. Sebuah Kritik: Arsitektur Yang Membodohkan, Jakarta: Gakushudo Publishing. 2015.

[14] S. Hahn. Tanda-tanda kehidupan, 40 kebiasaan Katolik dan Akar Biblisnya. Malang: Dioma Publishing. 2011.

[15] Y. D. Srisadono. Konsep Sacred Space dan Penerapannya dalam Gereja Katolik. Journal Melintas. Vol. 28(2), pp. 182-206. 2012. https://adoc.tips/konsep-sacred-dalam-arsitektur.html.

[16] R. Trisno, F. Lianto, The Meaning of Natural Lighting on Altar Case Study: Cathedral Church and Church of the Light, International Journal of Civil Engineering and Technology (IJCIET) 9(12), pp. 209-213. 2018. http://www.iaeme.com/IJCIET/issues.asp?JType= IJCIET \&VType $=9 \&$ IType $=12$.

[17] D. S. Capon. Architectural Theory Volume One. The Vitruvian Fallacy. Chichester: John Wiley and Sons. 1999.

[18] D. Stroik. The Church Building as a Sacred Place: Beauty, Transcendence, and The Eternal. Liturgi Training Publication Publisher. 2001

[19] M. S. Rose. The Three Natural Laws of Church Architecture, http://www.newoxfordreview.org/article.jsp?did=0909-rose. Retrieved Februari 05, 2017.

[20] J. Ratzinger. The Spirit of Liturgy. USA San Francisco: Ingnatius Press. 2011

[21] D. V. Twomey and E. Janet. Rutherford (ed.). Benedict XVI and Beauty in Sacred Art and Architecture. Dublin: Four Courts Press. 2011 . 